\title{
A Consideration on the Religious Education of the Old Testament in the Covid-19 Period
}

\author{
Saya Lee \\ Department of General Education, Namseoul University, Cheonan, Korea \\ isaiah37@naver.com
}

\begin{abstract}
Crisis has always existed in any era, but education is facing an unprecedented crisis due to Covid 19. Traditional teaching methods are often no longer valid. The pandemic situation caused by Covid 19 calls for a change in education methods. In particular, Christian religious education, which has adhered to the traditional education method, needs more change. Doing education is very difficult and at the same time one of the most valuable things today. Christian education today faces an unprecedented threat in the pandemic of Covid-19. The religious education of the Old Testament is also important in the Christian personality education. Religion education is the basic and core thing in all modern Christian education. But today, traditional religious education is facing a crisis. Rapidly developing technology, the recent decline in Christian worship due to Covid 19, and the change in social perception due to the ethical corruption of Christian leaders are widening the gap between generations. This intergenerational gap is also found in the Old Testament period. That is the gap between the Exodus generation and the wilderness generation. This intergenerational gap is also found in the Old Testament period. That is the gap between the Exodus generation and the wilderness generation. The purpose of this paper is to look at the problems of Christian education in the situation of Covid-19 and to clarify the meaning of religious education of the Old Testament focusing on Deuteronomy and today's Christian personality education.
\end{abstract}

Keywords: Religious education, Christian humanity education, Deuteronomy, Sherrill, Torah

\section{Introduction}

Most of the transitions in human history have come in a way that, when resistance to change weakens and old customs are struggling with a cracking system, customs are dismantled and the system collapses due to unexpected external shock [1]. The pandemic situation of Covid19 has brought changes not only in Korea but also in many parts of society around the world, and the change is still ongoing. The appearance of the changes that appeared after Corona 19 will allow us to experience a new everyday life called New Normal, and humanity will live in a new world that has not been experienced [2]. The same is true of Christian education, including education at Christian universities. The pandemic situation that has come in an era when various educations have not exceeded the limits of smartphones held in the hands of teenagers and college students can also reduce the limits of Christian education. Christian personality education is an education that takes place in an organic relationship with the faith community with Christ as the head on the basis of the conviction of being a child of God, the

Article history:

Received (January 12, 2021), Review Result (February 14, 2021), Accepted (March 17, 2021) 
ruler of history [3]. In this era where different generations are formed and lived as communities within the same era, Christian personality education begins with God's work and is an education conducted under God's guidance. In this era where different generations are formed and lived as communities within the same era, Christian personality education begins with God's work and is an education conducted under God's guidance. This paper aims to find the meaning of religious education that modern Christianity should bear, focusing on the Deuteronomy of the Old Testament, and to re-examine the meaning of Christian personality education that the community living in the post-covid-19 era should recover.

\section{Religious education of the old testament}

The typical catastrophes in the Old Testament are the destruction of Jerusalem and the temple in 586 BC. Sherrill explains the religious education of the Old Testament by dividing it before and after the catastrophe of 586 B.C. [4].

Until the fall of the kingdom, 586 B.C., there were no special forms of school education in the Old Testament and no specific teachers. However, parents, prophets, and priests who were in contact in life played the role of teachers, and education by parents was very important, and the Shema (Deuteronomy 6,4-9) was thoroughly practiced. The family was thought to be a channel of God, and family education was carried out through vocational education for survival, controlled by the father's absolute authority, and practiced by parents at home by oral tradition, and the main content was about religious consciousness. The core idea of law education is based on the Israelites' faith in the exodus. Parents made the teaching of these historical memories to the truths of the oral or written law to their children at home as the core of their education.

After the fall of the kingdom, the Hebrew education changed from the traditional way. In a national crisis, the so-called remnant or servants of suffering taught in the synagogues the Torah, known as God's will, or law. Instead of the parents of the family, the head of the synagogue was in charge of religious and educational activities, and there was an expert in the synagogue called Hazzan, who assisted in ceremonies and was in charge of education. The educational contents were shema, prayer, reading the Bible, interpretation of the Bible by the prophet, and the benediction of the priest. It is noteworthy that in this era, educational awareness began to be organized and institutionalized.

A school in charge of elementary school, called Beth Hassepher (house of books), appeared, and from the age of 6 , the Torah was read and memorized teaching methods were conducted. The educational institution responsible for the secondary and tertiary courses was Beth Talmud or Beth Hammidrash (house of research). Here, education was mainly conducted with questions, answers, and explanations. The final form of formal education was the Academy, a place where the Torah was studied in the same process as a modern seminary. The content of religious education in the Old Testament was mainly knowledge of knowing the revelation and will of God, and the content was specifically the Bible, especially the Torah.

\section{The contents of the religious education}

\subsection{Torah}

The basic meaning of the Hebrew Torah is teaching. It is a noun from the verb yarah (teach). The content of the teaching is how Israel will live as God's people. The basic teaching of the Old Testament is that because God taught Israel the way to live, Israel must live according to the teaching of God, that is, the word of the Torah. The Israelites accepted the Torah from God with gratitude. 
And this teaching of God, the Torah, is mainly in the form of laws and regulations. In other words, in the form of expression, it appears as a rule such as "You shall not have any other gods other than me" or "You shall observe the sacraments in the fall." So, in general, the Torah came to be understood as laws, and because the words and teachings of God appear mainly in the form of laws, the Jews call the Pentateuch as the Torah. There are 613 laws in the Pentateuch. Among them, there are 365 things that God's people should not do (=negative commandments), and 248 things (=positive commandments) to do. Each of these numbers corresponds to the number of days in a year and the number of body parts. These numbers, which can be a coincidence, remind us of the meaning of keeping the words of teaching as we live our daily life [5].

\subsection{The ten commandments}

While the Israelites left Egypt and arrived at Mount Sinai and stayed at the foot of the mountain, God called Moses up the mountain and taught them what the Israelites should keep. During the 40-year wilderness journey, the Israelites stayed on Mount Sinai for a short period of less than a year. However, the so-called Mt. Sinai paragraph (Exodus 19:1-Numbers 10:10) became an integral part of the Old Testament and became an important word defining Israel as God's people.

If God's teachings and laws received from Sinai are the core of the Old Testament, the Ten Commandments are the core of laws, the constitution of Israel, and the root of Israel's religion and ethics. The Ten Commandments were written on two tablets written by God twice (Exodus $24: 12 ; 31: 18 ; 34: 1,28)$. Although the first two tablets were broken and disappeared due to the people's idolatry, the second two tablets of the Ten Commandments Moses received was kept in the ark. The ark containing the stone tablets of the Ten Commandments was moved to Jerusalem in the time of David, but the Old Testament provides no information about what happened to the ark when the temple was destroyed in 586 B.C. Unfortunately, since creation, the only two stone tablets that God created by himself must have disappeared from history.

However, in the Pentateuch, in addition to Exodus 20, there is a part where another Ten Commandments appear. That is Deuteronomy 5:6-21. Deuteronomy is a sermon that Moses delivered to the wilderness generation, not the Exodus generation, in the land of Moab on the verge of entering Canaan. The wilderness generation is those who have not experienced the sufferings and calamities in Egypt. It was a generation that had been told through their parents without experiencing the miracle crossing the Red Sea or the idolatry and punishment at Mount Sinai. However, in the Ten Commandments appearing in Deuteronomy, there are other parts from the Ten Commandments that appear in Exodus. These are the fourth commandment, 'You shall observe the Sabbath,' and the tenth commandment, 'You shall not covet.' For the Exodus generation, it is said that God created the world and rested on the sixth day as the reason for keeping the Sabbath day holy, while for the wilderness generation, it is the case of salvation that led the people who lived as slaves in the land of Egypt. And the words that were told not to covet the neighbor's house have been replaced with the words to the wilderness generation not to covet their wives. Not only the audience who hears the Ten Commandments, but also the contents of the commandments have changed.

\subsection{Shema}

Shema (Deuteronomy 6:4-5) is the core of the teachings of religious education in the Torah. Originally, Shema is the imperative form of the verb shama (listen). This is the beginning of Deuteronomy 6:4, which became the Hebrews' confession of faith and educational guidelines. 
According to the tradition of the rabbis, the shema originally referred to only Deuteronomy 6:4, but later became included in verses 5-9, and furthermore, the second part (Deuteronomy 11:1321 ) and the third part (Numbers 15:37-41) came to have a broad meaning of shema.

In the shema, the belief in one god, the core of the Old Testament belief, is well revealed. The monotheistic belief that Israel, who lived in a culture where all kinds of 'other gods' were flooded, serves one God with all his heart, with all his character, and with all his strength, is the core of the Old Testament faith. If this faith is destroyed, the faith in Israel cannot exist. If anything in this world other than one God becomes the object of absolute loyalty, it becomes idolatry. The greatest $\sin$ in the Old Testament faith is idolatry (Psalm 44:15-20; Isaiah 40:1826; Jeremiah 10:3-5).

As dangerous as idolatry was the Religious Syncretism practiced by most Israelis in the Old Testament. For example, in 1975, Meshel of the University of Tel Aviv found a text record in Kuntilet Ajurud (Hebrew Horvat Telman), which was a surprise to the Old Testament academia. The contents are as follows.

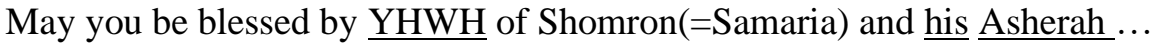

May you be well and be blessed by YHWH of Teman and his Asherah...

It is presumed that the Israeli priests who lived here blessed passing merchants. This is one of the archaeological evidences showing that the religion of Israel in the Old Testament was contaminated with Baalism and had a syncretism character. In the midst of this syncretism, the Shema demands the purity of faith and the one God that God's people must possess.

There is another important point in shema. It is a "command" to love one God. In our way of thinking, love cannot be commanded because it is primarily an emotional dimension. However, Shema is commanding, "Love God with all your heart, character, and strength." Because love in the Old Testament is not simply an emotional dimension. It is a dynamic and educational concept in which love is established only when a behavioral dimension is involved. Then, how can we specifically follow the command to love God? To obey(shama) God's word is to love God (Deut. 28:1-2,15). Love for God cannot be proved only by feelings and words. So, in Deuteronomy, the words ahav (love...God) and shamar(keep...the word God has given) are mostly followed together (Deut. 7:9; 11:1).

Religious education in the Old Testament emphasizes the dynamic faith embodied in the life of faith. No matter how much we shout out to be God's people, we cannot be said to be God's people unless we are seen by living the life of God's people. It was the result of God's great grace that God bestowed upon them that Israel became God's people. For this great grace of God, Israel must live a life that responds correctly to God's Word. These characteristics and nature of the Old Testament faith are also applied to the New Testament (Matthew 7:21).

\section{Deuteronomy and generations}

The theological weight of Deuteronomy in the Old Testament is enormous as Gerhard von Rad, who is said to be the master of Old Testament studies in the 20th century, said, "The theological center of the Old Testament is Deuteronomy." It is also the book of the Old Testament that the New Testament is the most cited except for the Psalms ( 83 times). For example, when Jesus, who had finished fasting forty days, was tried by the devil in the wilderness, the three words he said against the devil are all quoted from Deuteronomy (Matthew 4:4=Deuteronomy 8:3, Matthew 4:7=Deuteronomy 6:16, Matthew 4:10=Deuteronomy 6:13).

The 40 years of life in the wilderness after Exodus was the history of Israel's disobedience and rebellion to God (Deuteronomy 9:6-7, 9:24). However, even in the history of such disobedience, it teaches us to live like God's people while obeying the Word of God 
(Deuteronomy 8:11-20). When the Israelites enter the promised land and live, it can be said that Deuteronomy is the record of the words Moses re-explained about the norm of life that must be observed.

The central theme in the Old Testament is the special relationship between God and Israel. God is the God of Israel, and Israel is the people of God. Israel was a specially chosen people as God's people. Why did God specifically choose Israel among many people? What wonderful things made the Israelites the chosen people? To this question, the Old Testament answers. The reason God chose Israel was because He loved Israel (Deuteronomy 7:6-8). There are many peoples on earth, but God has made Israel a special distinction for his people. The term segula (treasure) is also a language used in connection with choice. God made Israel his special treasured possession [6].

We can raise the question again, "Why did God love Israel?" God loved and chose Israel not because they had special conditions to be loved. Israel's becoming a people of God is a gift of God's 'grace', given without any conditions. On the other hand, for Israel, to be a people of God was an indescribable glory and a great privilege that other people could not enjoy. However, just as a coin has two sides, there is another side to the fact that God chose Israel. It is that Israel is God's chosen people, so they must live like God's people and like the chosen people. The privilege of Israel's choice as a chosen people comes with a corresponding responsibility. Religious education in the Old Testament gives the answer to this very question.

Many of God's teachings that appear in the Torah are now not kept. For today's Christians, Easter, Christmas, and Thanksgiving are heavier and more friendly than Passover, Feast of Week, East of Booths. Christians worship without sacrificing cattle or sheep. They do not follow the Jewish kosher, so they enjoy pork to their heart's content (Leviticus 11:9-11). No tefillim are attached to the wrist, nor is mezuzah attached to the doorpost of the house (Deuteronomy 6:8-9). Is it really wise for us in the age of technology to live with the teachings of the Old Testament still holding to the measure of faith and ethics? These questions also existed in the Old Testament times. Moses tried to bridge the gap between the Exodus generation and the wilderness generation with "the contemporaneity of the covenant': "Yahweh our God made a covenant with us in Horeb. Yahweh didn't make this covenant with our fathers, but with us, even us, who are all of us here alive this day" (Deuteronomy 5:2-3). He wanted the new generation to apply God's Word anew. He was shouting 'the contemporaneity of the covenant' that spans generations and times. This contemporaneity still applies to us reading the teachings. It is certainly difficult and not desirable to apply all the teachings that appear in the Old Testament in this age. However, the reason why the contemporaneity of the covenant is applied in this age is because the spirit flowing in the teaching is still the same.

After the Exodus, while the Israelites lived in a life of suffering in the wilderness, God Himself taught Israel the way to live as God's people through Moses. The first is the Torah from Sinai. This is recorded in Exodus 19 through Numbers 10:10. Second, just before entering the Promised Land, He gave the words of the Torah once again in the plains of Moab. This is recorded in Deuteronomy 12-26.

It gives an important meaning that all the words of the Torah that God gave to Israel were given during the wilderness period before entering the Promised Land. The wilderness life experienced by Israel was a series of extreme hardships and various hardships. However, religiously, this period was a period of grace that God gave Israel all the norms and rules for living as God's people. The period of suffering was the period of grace.

Deuteronomy tells us not to forget the history of salvation that Israel experienced, and to make known to your sons and your grandchildren (Deuteronomy 4:9). What is it to know? There is two main things Israel must remember and convey. The first is the Exodus case. The 
event that brought Israel into a free community is the Exodus event, and the God of Israel as a community is the God of the Exodus above all else [7]. So, remembering the events of the Exodus does not mean simply remembering events in the past, but also remembering God who saved his suffering people. Second is the memory of life in the wilderness. They must remember the events of rebellion against God during the 40 years spent in the wilderness and God's faithfulness toward Israel [8]. What was needed for this was education for religion and religion (Deuteronomy 4:1; 5:1).

Behind this emphasis lies the difference between the generations of the Exodus and the wilderness. The generation of the exodus knew all great things that the Lord did (Deuteronomy 11:7), but the generation of the wilderness did not know the miracles that took place in Egypt during the Exodus (Deuteronomy 11:2-3), and the miracles that happened when their fathers crossed the Red Sea. They never experienced any historical events such as the enemy's work (Deut. 11:4), and Israel's disobedience in the Sinai wilderness (Deuteronomy 11:5-6). Conflicts between generations have existed at all times. The Old Testament teaches that these two generations should be solved by education. It was the responsibility of the Exodus generation (Deuteronomy 4:9; 6:6-7; 11:18-19).

\section{Conclusion}

In 2020, everyone expected that the advancement of computer-based convergence technological science in the era of the 4th industrial revolution will be combined with the fields of physics, digital, and biology to make human life more comfortable and happier. However, such expectations and hopes have changed into an environment of concern and despair due to the Covid-19 pandemic that appeared in the early 2020 [9]. The pandemic situation of Covid19 is calling for a total change in Korean Christianity and the church. Just as the Exodus generation and the wilderness generation had to live in a completely different era, today's era also has difficulties in different communities that must follow the changed trend within the same era. However, there are important principles in the survival of all communities that should not be lost in the midst of change. The Book of Deuteronomy in the Old Testament presents important principles that the Christian community should not lose. In the Old Testament era, the most important place for religious education was at home. At home, parents had to strive to teach their children the Torah and the legacy of faith. Parents did not fulfill their responsibilities by providing only abundant food, clothing, and shelter for their children. He had a responsibility as a religious educator at home. The reason parents were the most important educators of faith, character, and religious education is that as they entered the ancient times, they spent more time at home. This was the same for education today.

How should Christianity and religious education accept the post covid-19? In human history, Christianity shined through its existence during crisis. The credibility of Christianity, which has fallen in Korean society, can be restored when the community experiences the spirit of Christianity and the sincerity of the church. Although the difficulties caused by the covid-19 continue, through suffering, we will become stronger internally and trained into mature beings. We will have to practice a wise lifestyle with a long breath while reflecting on our way of life with a positive and optimistic mind [10]. If we vaguely wait for a new era, nothing is given. What is given is an unexpected crisis, and overcoming it is the human will. Deuteronomy presents a path for the wilderness generation who must live in a new era different from the Exodus generation. It will be said that it is the responsibility given to us to live in the postcovid-19 era to pursue a world that fits the values pursued by each community in a changing era, but to keep the values that should not be lost amid those changes. 


\section{References}

[1] S. Lim, "Nothing is given: how the world will face the post corona," The Christian World 1064, pp.14-17, (2020.05)

[2] J. Kye, "A study on the direction of christian leadership Post-COVID19," University and Mission 44, pp.153178, (2020)

[3] I. Oh, "Christian education," Korean Society of Christian Education, pp.161, (1984)

[4] L. J. Sherrill, "The rise of christian education,” New York: Macmilan, (1944); J. Eun, "Theology of education, Seoul: Dongyeon," pp.100-113, (2013)

[5] S. Lee, "Encounter the old testament," Seongnam: Bookorea, pp.106, (2016)

[6] S. Son, "Love god only,” Deuteronomy, Seoul: Duranno, pp.280 (2008)

[7] J. Kim "Remembering faith: Piety and spirituality of Deuteronomy," Seoul: kmc, pp.163, (2015)

[8] ibid. 164

[9] J. Kim, "With-Covid19 period," New direction of spiritual education for the elderly," 49th Annual Conference of KACS, pp.272-292, (2020)

[10] J. Lee, "Social problems caused by COVID-19 and their solutions," University and Mission 45, pp.61-90, (2020) 
A Consideration on the Religious Education of the Old Testament in the Covid-19 Period

This page is empty by intension. 